\title{
Innovation and implementation of fabrics with luminous yarns using weaving machine with jacquard
}

\author{
Sanaa Saleh $^{(1)}$, Ossama Halawa ${ }^{(2)}$, Rania Seif Al-den ${ }^{(1)}$, Abeer Al-hems ${ }^{(1)}$ \\ (1) Faculty of women for Arts, Sciences and education, Ain shams university. \\ (2) Faculty of Applied Arts, Helwan university.
}

\begin{abstract}
The Victorian era enriched textile design industry with floral designs by many designers who contributed to arts and crafts movements in this era, William Morris is considered as one of the surface textile pioneers whose designs are still masterpieces from century ago until now, Innovative luminous fabric design inspired by William Morris is generated by Adobe Illustrator and implemented by jacquard machines using computer-aided design software to control different weaving parameters, the luminous fiber with a long afterglow is produced by adding the rare-earth strontium aluminate powder to the polymer by a melt spinning process and it's infrequently used in the industry.
\end{abstract}

Keywords: luminous yarn, jacquard machine, textile design

\section{Introduction and literature of review}

\subsection{Victorian Era}

This era was known as the period of floral designs and the base of today's many floral patterns, it was remarkable for the rules established for arranging flowers within designs and arranging repeating where symmetrical ogee arrangement was the favorite, also flowers with strong brilliant colours were preferred. One of leader designers in this era was William Morris (1834-1896) who encourage the famous Arts and Crafts movement in nineteenth century and used the traditional jacquard machine to turn his ideas into real fabric, he drew plenty of noteworthy floral designs. Figure (1) shows one of his famous water colour and pencil floral painting which is in Victoria \& Albert Museum in London ${ }^{(1)}$.

Furthermore, the symmetrical figures were very popular in this era where a unit, which is used two or more times in forming a complete figure, is having two symmetrical halves, one of them is painted and mirrored. some living creatures such as birds and some fruits were also added to the Victorian designs.

\subsection{Luminous yarns}

Luminous fiber is a polyester fiber consists of four components blended together with a melt spinning process: rare-earth luminescent materials and fiber-forming polymer (polyethylene 
terephthalate) as the two fundamental components with the addition of transparent inorganic pigment and $0.5 \%$ functional additive. Chemical composition of luminous fiber is $\mathrm{SrAl}_{2} \mathrm{O}_{4}: \mathrm{Eu}^{2+}, \mathrm{Dy}^{3+}$ (SAOED: strontium aluminate phosphors) ${ }^{(2-6)}$.

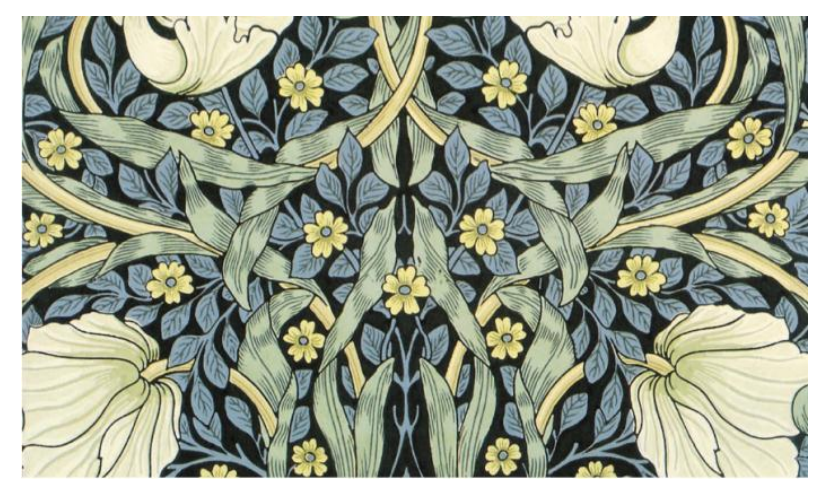

Figure (1): One of William Morris pencil and water colour floral designs .

The luminous yarns became an interesting research area recently; the fiber has special characteristics different from the normal yarns such as emitting light in the dark after storing energy from whether artificial or natural light sources, the yarns not only display a luminous decorative effect in the dark but also improve vision in case of lighting off as seen in figure (2) ${ }^{(2,3,7-9)}$.

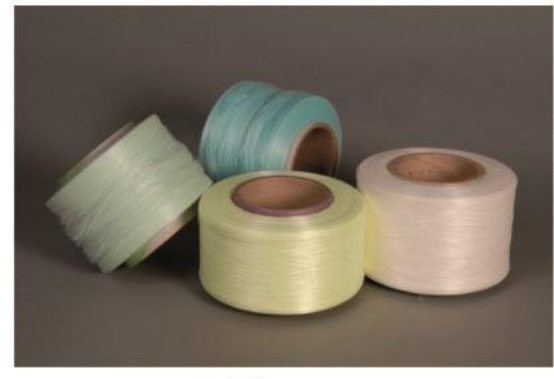

lighting

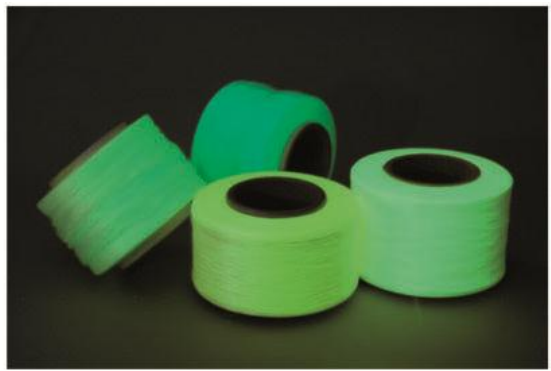

without lighting

Figure (2): Luminous yarns under the conditions of lighting and without lighting. (10)

Although the fiber is not significantly used in the textile industry, some endeavors took place in the recent ten years to integrate the fiber into fabric by different means like embroidery, knitting and weaving. Many factors can affect the produced fabric properties, in case of embroidery, parameters such as stitch type and stitch spacing affected the afterglow intensity of the fiber and its aesthetic properties, on the other hand, the fabric pattern which is produced by using the luminous yarn can considerably match its digital image like any other normal yarn ${ }^{(8,11)}$.

Integrating the fiber into fabric by weaving means still needs further study, different weaving machines can be used for this purpose like the jacquard machine which is special for its decorative fabric designs and the ability to control every warp yarn separately, similar to embroidery, the different weaving parameters such as weave structure and fabric type can highly affect the luminous pattern in the dark, that's because different weave structures have dissimilar degrees of appearance on the fabric surface depending on 
the weave structure float size, fabric density is also a major factor because it affects the emitted light intensity. Using jacquard CAD system makes it easier to control all weaving parameters and adapting them to the desired final fabric ${ }^{(12)}$.

\subsection{Adobe illustrator}

Adobe Illustrator is the main program chosen for creating and drafting design motifs, it contains many options and tools for all drawing purposes. Two of the most important features of the software especially for the textile design drawing are the ability to repeat motives located on the edges of the design at the other sides in order to complete each other and obtain an exact matching when repeating the design unit from all the sides, the second feature is the mirroring option while drawing the symmetrical designs which is very beneficial to the construction of jacquard decorative designs where the drawing in one half of the design area is automatically mirrored in the other side, a symmetrical design constructed by mirroring is shown in figure (3), this feature maintains accuracy and saves lots of time.

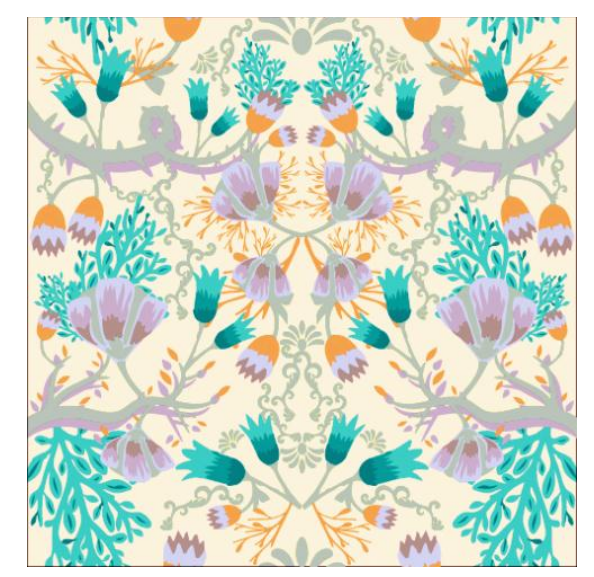

Figure (3): symmetrical design constructed by mirroring option in Adobe Illustrator.

1.4. Methodology: this research belongs to the applied methodology.

2. Materials and Methods

\subsection{The materials}

The luminous yarns are used for weaving process alongside with different normal yarns. The specification of the luminous yarns is shown in table (1).

Table (1): yarn specification.

\begin{tabular}{|c|c|c|}
\hline & Warp yarns & Weft yarns \\
\hline Yarn Type & Dyed cotton & $\begin{array}{c}\text { Dyed cotton } \\
\text { luminous polyester }\end{array}$ \\
\hline Yarn count & $30 / 1 \mathrm{E}$ & $\begin{array}{c}30 / 1 \mathrm{E} \\
175 \times 2 \mathrm{D}\end{array}$ \\
\hline Yarn density & $36 / \mathrm{cm}$ & $48 / \mathrm{cm}$ \\
\hline
\end{tabular}




\subsection{The machines used}

Jacquard machine was used for fabric production. Loom and machine specification is shown in tables (2) and illustrated in figures (4).

Table (2): loom and jacquard machine specification.

\begin{tabular}{|l|l|}
\hline \multicolumn{2}{|c|}{ weaving machine and jacquard specification } \\
\hline Jacquard Name & BONAS \\
\hline Jacquard Model & LJ6 (Electronic) \\
\hline Manufacturing Year & 2014 \\
\hline Jacquard Hooks & 6144 hooks \\
\hline Design Hooks & 5800 hooks \\
\hline Repeats number & One Repeat \\
\hline Fabric width without & $161.1 \mathrm{~cm}$ \\
\hline selvedge & \\
\hline Fabric width with selvedge & $163.1 \mathrm{~cm}$ \\
\hline Warp density & 36 yarn/cm \\
\hline Reed used (dents/cm) & 9 dents/cm \\
\hline Denting & 4 ends/dent \\
\hline
\end{tabular}

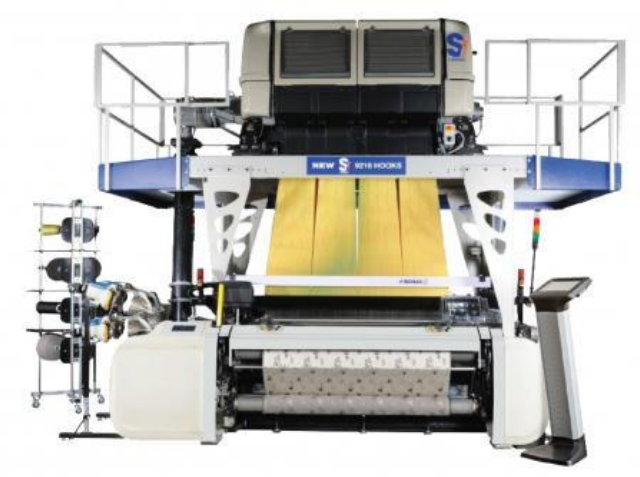

Figure (4): Bonas jacquard machine.

\subsection{The methods}

The luminous yarns have been woven in some chosen areas of the fabric and during the production process, they have been blended with other normal yarns. The integrating process of the luminous yarns carried out using two different methods:

1. Extra weft method: to apply this method of weft cramming, certain parts of the cloth to glow in the dark were chosen and when the turn came to those selected parts, the thread is involved in the weaving process and temporary paused when moving to 
another part. Figure (5) illustrates the extra weft method applied for a jacquard fabric design.

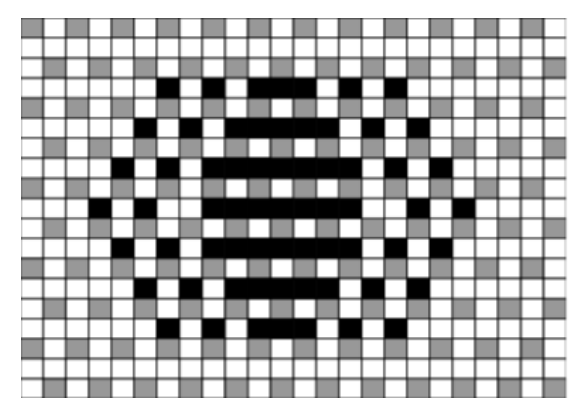

Figure (5): extra weft method applied for a jacquard design.

2. Weft-Backed cloth: many sets of warp and weft yarns were used to apply the weft backed technique with many complex weave structures, to apply this method four weft yarns were used.

\subsection{Test methods}

1- Tensile strength: ASTM D2256-09 test method was used to measure the tensile strength of the yarn. The tensile strength values are shown in table (3).

2- Yarn twist: twists in the yarn were measured using test method ASTM-D1423, the number of twists are shown in table (3)

Table (3): mechanical properties of the luminous yarns.

\begin{tabular}{|c|c|c|c|}
\hline $\begin{array}{c}\text { Yarn } \\
\text { sample }\end{array}$ & $\begin{array}{c}\text { Tensile } \\
\text { strength(N) }\end{array}$ & $\begin{array}{c}\text { Elongation } \\
(\boldsymbol{\%})\end{array}$ & $\begin{array}{c}\text { Number } \\
\text { of twists }\end{array}$ \\
\hline 1 & 18.6 & 33 & 195.1 \\
\hline 2 & 19.7 & 39 & 223.2 \\
\hline 3 & 19.5 & 37 & 203.3 \\
\hline 4 & 18.7 & 37 & 180 \\
\hline 5 & 18.8 & 38 & 212.6 \\
\hline
\end{tabular}

3- Yarn count: Yarn count was measured using test method ASTM-O 1907-1.

4- Light fastness: Light fastness properties of the luminous yarn were measured based on method AATCC 16A-1989. The results of the test are shown in table (4).

5- Wash fastness: Wash fastness properties of the luminous yarn were measured based on method ISO 105-CO2 (1989). The results of the test are shown in table (4). 
6- Perspiration fastness: Perspiration fastness properties of the luminous yarn were measured based on method (ISO 105 - E04(1989). The test results are shown in table (4).

Table (4): fastness properties of the luminous yarns

\begin{tabular}{|c|c|c|c|}
\hline Sample & $\begin{array}{c}\text { Change in colour } \\
\text { (Light) }\end{array}$ & $\begin{array}{c}\text { Change in colour } \\
\text { (Wash) }\end{array}$ & $\begin{array}{c}\text { Change in colour } \\
\text { (Perspiration) }\end{array}$ \\
\hline Green & 6 & $4-5$ & 5 \\
\hline Blue & 6 & $4-5$ & 5 \\
\hline Yellow & 6 & $4-5$ & 5 \\
\hline Pink & 6 & $4-5$ & 5 \\
\hline
\end{tabular}

\section{The results and discussions}

\subsection{Specification of design and fabric}

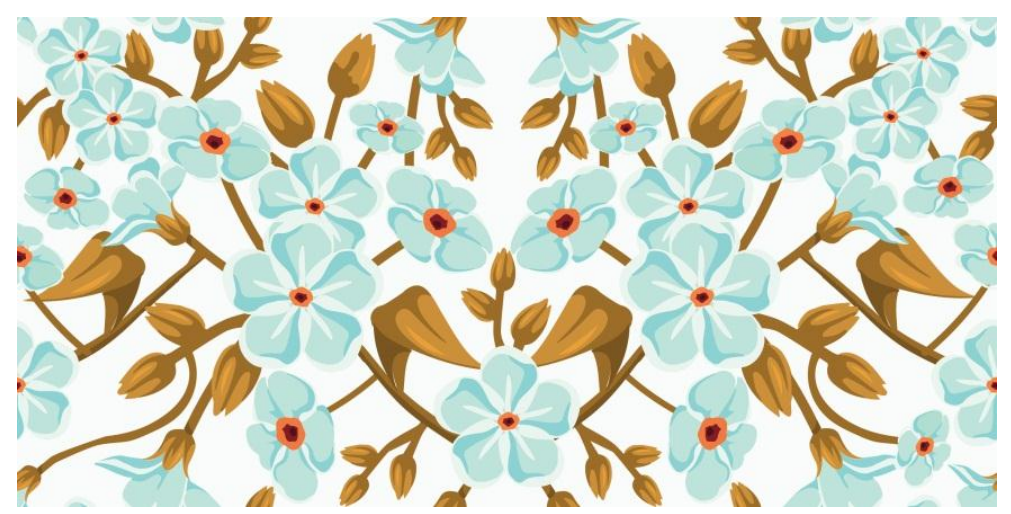

Figure (6): Digital image of the Design.

In this design, the "forget me not" flower which is one of the most famous British flowers is chosen for the floral pattern with its azure bright petals as shown in figure (6). It was commonly used in the Victorian era as a gift flower and from its name, it was given by a person who wanted to be remembered.

\subsubsection{Design properties and construction:}

- Main motives: the "forget me not" blossom with different three appearances; the flower buds, partially and fully blooming flowers with leaves.

- Design construction: bi-symmetrical construction was chosen where the motives were distributed in a half of the design area and then, this half was turned over exactly in the other half. Using Adobe illustrator, while drawing in one half of the design, a mirrored drawing is automatically taking place in the other side. 
- Design production stages: the figure (7) illustrates the production stages of the design:

1- Drawing the first faced flower with a selected colour palette.

2- Adding flowers from different angles and different growing stages with some leaves, the colour palette was also changed.

3- The pattern implementation was carried out using the mirrored method in Adobe Illustrator where drawing takes place in one half of the screen and the other half is automatically drawn exactly as the first one.

4- After motives distribution and overlapping, the motives that located in the edges were set to complete each other when repetition using the software options.

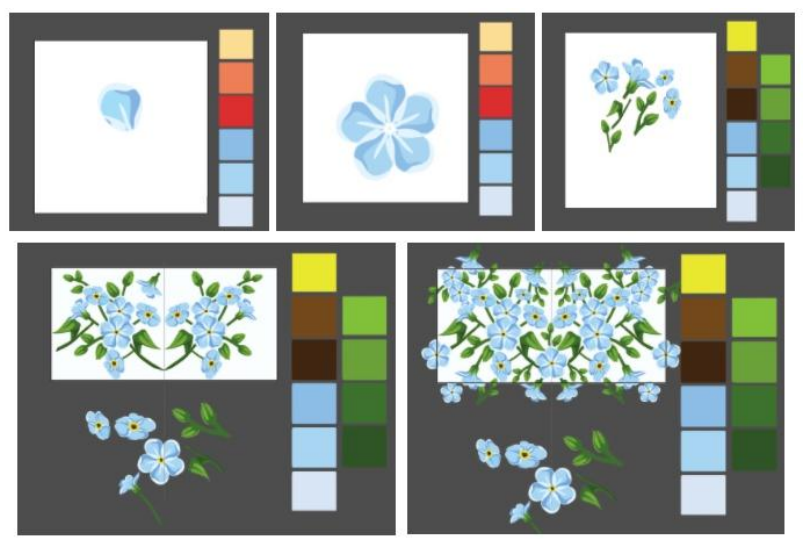

Figure (7): design production stages in Adobe Illustrator.

\subsubsection{Design weaving parameters and properties}

Different weave structures are sprayed on the whole motives and background of the design to obtain every desired colour and effect, the different weave structures which are used in the design are shown in figure (8):

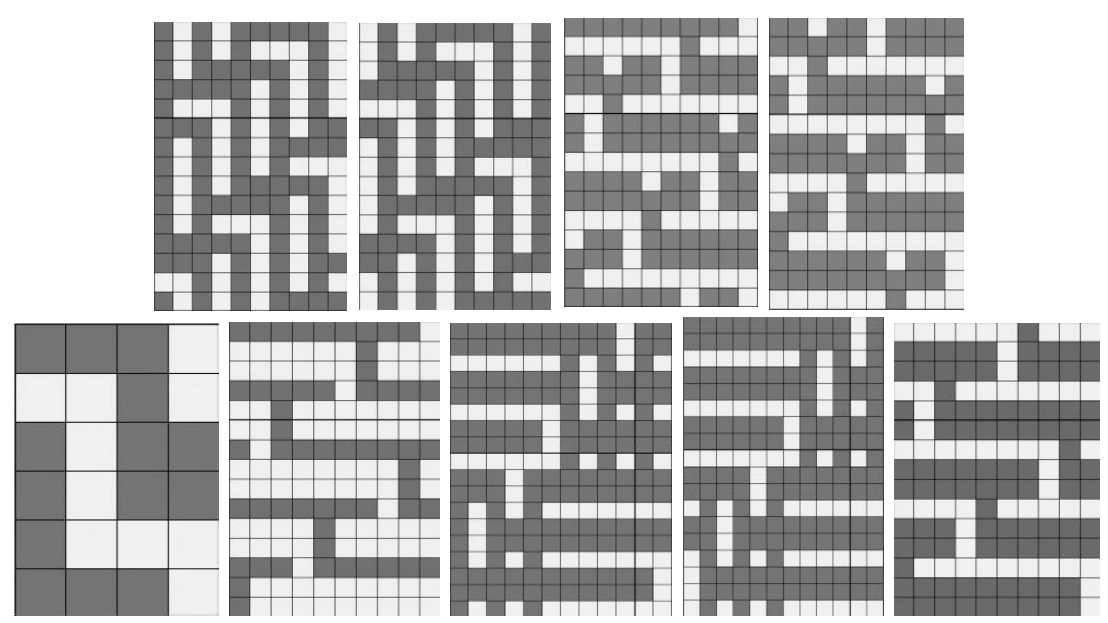

Figure(8): different weave structures used for fabric production. 
The fabric has weft-backed structure and luminous yarns are presented in the three blue flowers in the middle of figure (9). The luminous flowers have two different shades of blue due to using two different colors of warp yarns (face and back yarns) during weaving.

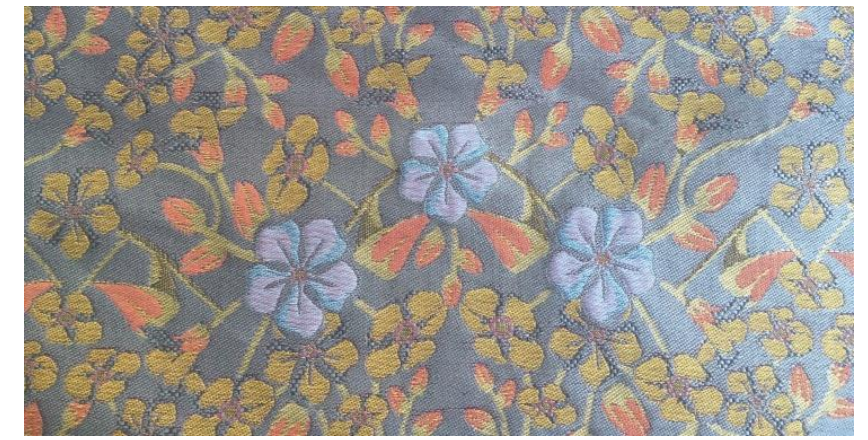

Figure(9): implemented fabric of design (1) using jacquard loom.

Problems in fabric: the two shades of the luminous flower which illustrates the light and dark in the flower were clearly appeared in the light condition but hardly seen in the dark, this difference between shades appeared as one light block with no effect when in the dark, the reason for this is using the same weave structure for both shades with only changing the faced warp yarns so, when the light is off, the warp yarns disappear and resulted in losing the two shades effect.

\subsection{Fastness properties of the luminous yarns}

Luminous yarns tend to be continuously exposed to light and for long periods of time to restore energy and emit it, and therefore a well light resistance is essential and required to enhance the lifetime of the luminous fiber products, on the other hand, in case of using the yarns for producing wearable fabrics, exposure to washing and perspiration is unavoidable. The yarns show remarkable fastness properties against washing, light and perspiration which made it possible to use them in the industry and wearable fabrics mass production.

\section{Conclusion}

The luminous yarns are integrated into fabric by weaving process to give a luminous effect in the dark, the luminous fabric design was generated using Adobe Illustrator software and the designs were inspired by William Morris, motives are constructed and distributed evenly in the pattern design area, then the computer-aided jacquard software is used to modify and adjust the weaving construction parameter such as different weaving structures and fabric type. the fabric gave a decorative effect in the dark and a luminous effect in condition of light off and show a good resistance to light, wash and perspiration in order to use them afterward in the industry of wearable textiles. 


\section{References:}

Sinclair R. Textiles and Fashion: Materials, Design and Technology. UK: () Elsevier Ltd; 2015. 845 p.

Yanhong Yan MG, Yonggui Li, DNT Kumar. Morphology and spectral characteristics of a luminous fiber containing a rare earth strontium aluminate. Textile Research Journal. 2012.

Ebrahimzade A, Mojtahedi MRM, Semnani Rahbar R. Study on characteristics and afterglow properties of luminous polypropylene/ rare earth strontium aluminate fiber. Journal of Materials Science: Materials in Electronics. 2017;28(11):8167-76.

Yu Y, Wang J, Wang J, Li J, Zhu Y, Li X, et al. Structural characterization and optical properties of long-lasting $\mathrm{CaAl} 2 \mathrm{O} 4: \mathrm{Eu} 2+, \mathrm{Nd} 3+$ phosphors synthesized by microwaveassisted chemical co-precipitation. Journal of Rare Earths. 2017;35(7):652-7.

Zhu Y, Ge M. Study on the emission properties of Sr2MgSi2O7:Eu,Dy for luminous fiber application. Journal of Materials Science: Materials in Electronics. 2014;25(12):5512-7.

Yan Y, Liu C, Ding X. Study on the equivalent luminance of luminous fibers in photopic vision and scotopic vision. Textile Research Journal. 2017.

Guo X, Ge M. The afterglow characteristics and trap level distribution of chromatic rare-earth luminous fiber. Textile Research Journal. 2013;83(12):1263-72.

Radavičiene S, Jucienė M, Sacevičiene V, Sacevičius R, Otas K. Investigation and assessment of photoluminescent embroidered elements. International Journal of Clothing Science and Technology. 2014;26(1):38-47.

Yan Y, Zhu Y, Guo X, Ge M. The effects of inorganic pigments on the luminescent properties of colored luminous fiber. Textile Research Journal. 2013;84(8):785-92.

Guo X, Zhang K, Zhang H. Working Conditions on the Afterglow Characteristics of Rareearth Luminous Fibers. Fibers and Polymers. 2018;19(3):531-7.

Li J, Chen Z, Ge M. Computer-aided design of luminous fiber embroidered fabric and characterization of afterglow performance. Textile Research Journal. 2015;86(11):1162-70.

Wang J, Yang B, Huang B, Jin Z. Design and development of polymeric optical fiber jacquard fabric with dynamic pattern display. Textile Research Journal. 2011;82(10):967-74. 


\section{الملخص باللغة العربية}

\section{ابتكار و تنفيذ أقمشة تحتوي علي خيوط ضوئية باستخدام ماكينة الجاكارد}

عبير عبدالله الحمص ['] ،سناء صلاح الدين صالح ['] ، أسامة عزالدين حلاوة [] ، رانيا صادق سيف الدين [']

يتميز العصر الفيكتوري بتصاميمه الر ائعة التي احتوت معظمها على الزخارف النباتية وكان من أثهر مصممين العصر الفيكتوري ويليام موريس الذي تميزت تصاميمه بدمج أنواع مختلفة من النباتات و تنتابكهم مع بعضهم البعض في نفس التصميم وقد تم استلهام التصاميم التي استخدم فيها الخيوط الضوئية من تصاميمه وتم تصميمها باستخدام برامج الحاسب الالي التي سهلت عملية التصميم بشكل كبير مع وجود أدوات جعلت رسم الزخارف وتكر ار ها داخل التصميم و علي حافاته ايسر و ادق كما انها كانت تتميز بوجود مكتبة من المجموعات اللونية و التي استلهم منها الوان التصاميم، كما تم بعد ذلك استخدام هذه التصاميم لنسج عينة استرشاديه من القماث المزدوج محتوية علي الخيوط الضوئية باستخدام ماكينة الجاكارد و تميزت هذه الخيوط بخصائص منفردة عن باقي الخيوط العادية في انها تحتفظ بالضوء في فترات الصباح او الانارة و تنتير في الظلام و للمحافظة علي هذه الخيوط من الهدر ساهم التحكم الاليكتروني في خصائص الماكينة علي توظيف الخيوط و نسجها داخل الأقشة في أماكن محددة باستخدام تقنية اللحمة الز ائدة. 